\title{
Historical Causes of Militancy and Its Impacts on Educational Institutions in the World
}

\author{
Alamzeb Khan \\ Student of Ph.D, Insitiute of Development Studies, The University of Agriculture Peshawar \\ Dr.Naushad Khan \\ Advisor of the Students Assistant Professor, Institute of Development Studies, The University of Agriculture \\ Peshawar
}

\begin{abstract}
The study was carried out since May, 2019. The major objective was that to find out historical causes of militancy and its impacts on education in the world. Total 40 studies were downloaded from the net and was reviewed again and again and analyzed the situation about the historical causes of militancy and its impacts on education in the world. The study indicates that It is the historical game of the world which are used for gaining the power over the world. All the world developed and under developing countries are involved in this game. Similarly the poor community and illiterate people are deceived by this game and give money for gaining their objectives and purpose. In this game schools, hospitals, road and bridges are destroyed while sometime people are killed for pressurized the government for weakening the economy of the country. Since 1979 the Russia attacked on Afghanistan and this time US allied forces defeated to Russia and this time Asama Bin ladin was the part of US allied forces while latter on in 9/11 he was wanted to USA in this case. Such type accidents were also observed in Iraq, Turkey, Sirilanka, Bangladesh, India, Labia, Egpt. Sham, Pakistan, Malishiya and Syria etc. The militants also there attacked on the administration machinery and want that to downfall the system of the country. The record shows that million people were killed and number of school, colleges and hospitals were destroyed by bomb blasting and number of students was dropped out due to terror from the schools and colleges. Review of related literature shows that militancy is causing aggression in society in terms of cause and interest. In every society the militants are the production of socio-economical imbalanced systems. It also explores that poverty prevailed in society is mainly causing militancy. Thus militancy is not only affecting economy (in terms of spending money on war of terror) but can also have impacts on the physical shape of the society. Insecurity in educational sectors increases illiteracy (dropout rate). While terrorist attacks are directly creating fear and psychological diseases like anxiety etc. among both the parents and students and even in teachers as well. Especially those students whose institutions are once targeted or still under influence of terrorism are avoiding education and they are suffering directly and facing bad consequences in future. The militancy raised due to poverty and illiteracy in the world which further used by some leader for gaining the power. They activate the poor illiterate community which has no knowledge about the game while they are deceived and unite them against the government which latter on became militants which have weapons which are used against the government and destroyed to schools and colleges and make the environment unfavorable and create terror in the world for pressurizing the government. On the basis of problems the study recommended that to generate employment for reduction of poverty and established school and colleges for the improvement of their skill to find job easily anywhere in the world for pushing their economy. All countries of the world boundary walls should be constructed for protection of for foreign militant attack. Strict rules and regulation by government should be imposed. Passport and Identity Card system should be developed in the country for arresting the militants who goes against the country.
\end{abstract}

Keywords:-Historical Review, Causes, Militancy, Impact, Education, World

DOI: $10.7176 / \mathrm{JAAS} / 58-04$

Publication date:September $30^{\text {th }} 2019$

\section{INTRODUCTION}

The modern world has seen unprecedented increase in militancy than the past decades. Thousands of people have become homeless while millions of children are on the verge of death. The necessary infrastructure has been ruined, including educational institutions, health facilities etc. Many developed countries spend their foreign reserves cope with the evil of militancy while ignoring other crucial sectors of development. Militancy is the state of being militant. The word militant, is both a noun and an adjective. It is derived from a latin word "militare" that meant "to leave as a soldier" in the $15^{\text {th }}$ century. . However, the present meaning of militant does not have to; and in fact usually does not refer to a registered fighter; it can be anyone at all who subscribes, either in partial or in whole, to the plan of using violence to achieve some objective, usually political or spiritual. The term militancy thus refers to a movement in which a group of people are busy in armed struggle to achieve an objective and thus hold an aggressive attitude in support of an attitude or cause. The description of militancy is 
violence and aggression for confirmation of their political or religious beliefs in the name of a group. Militants often have an extreme solution for their goals and their movement. Militants may fill their position either by volunteering or by recruitment. Politically unstable or less controlled society create traditional minds, then they performs their nonhuman activities (Rizvi, 2005).

Impact of militancy differs from region to region but it leaves bad effects on every sphere of life. Militancy affects financial development of a country that results in increase of inflation. Furthermore it brings down the process of development of a country (Bloomberg, 2004).

During 2007 to 2014, 78 per cent of the total militant attacks in the world occurred in ten countries. During this span 79 percent of terrorist incidents occurred in different parts of the world. Iraq was one of the most affected countries, where most of the terrorist incidents occurred, where total number of incidents were 30 percent of the world. While in Pakistan total number of incidents were 13 percent that labelled as a second most affected country of the world. The 9/11 incident was a serious issue of terrorist which got higher importance in Western countries like the Eastern countries and thus the whole world came under the influence of terrorism, especially education suffer the most (Shabir and Naeem, 2015).

The terrorism had badly affected the south Asia because of the unprecedented events in the region. Among the south Asian countries, Butan and Bangladesh are the most vulnerable, where both the civilian and tourists are at risk. Since the invasion of United States of America on Afghanistan, the scenario had changed which brought devastating effects for Pakistan. Pakistan has been directly affected through this militant operation but still the western world believes that terrorist groups were the product of Pakistan since eighties in Afghan war. The resulting effects were not well for Pakistan because of the world's perception that terrorists originates from Pakistan (Rahman, 2003, 2008) and expected more to do against the militant groups. In world different militant groups were initiated in different era. Among these groups Revolutionary Armed Forces of Colombia was established in 1964 and currently it constitutes approximately 12 thousand combatants with thousands of supporters from the rural areas. The obtained extortion money from multinational corporations and wealthier classes is invested for the betterment of poor peoples. Liberation Tiger of Tamil Eelam, deadliest terrorist group of Srilanka. It was founded by Velupillai Prabhakaran in May 1976, possessing a sophisticated military. However, it was defeated in May 2009 by Srilankan Military but it has a devilish record of assassinating highprofile Indian and Srilankan politicians. Banned by 32 countries across the world, this terrorist group was the main reason behind the Srilankan Civil War. Kurdistan Workers Party was established on November 27, 1978 in Turkey and since then it has been fighting for the sake of an independent Kurdish state. Face of an international terror, PKK's working region constitutes Turkey, Iran, Syria and Iraq and it is also enlisted by a number of counter-terrorism agencies as a deadly international organization. Hezbollah, backed up by Iran and Syria, this Lebanon based terrorist group has emerged from the Lebanese civil war of 1982 and is considered as the biggest foe of Israel and Sunni Arab countries. According to a report of Central Intelligence Agency, this organization covers the 41 percent of Lebanese population and is involved in multiple social activities. Hamas, Acronym for "Harakat Al-Muqawama Al-Islamia", HAMAS is a socio-political terrorist group of Palestine which was founded in 1987 due to an offshoot of the Muslim Brotherhood. This organization was established with the aim of Jihad and to release Palestine from Israeli subjugation. Known for its daredevil suicide bombers, this terrorist group is significantly supported by Hezbollah to assassinate Israeli civilians and defense officers. Al-Qaeda, the biggest "brand name" between all terrorist groups across the world! This extremist Islamic group was established in 1989 by Osama Bin Laden, the great grandfather of all terrorists and a mysterious figure dodging the worldwide intelligence agencies after the September 11 attacks. Notorious for its integrated network and powerful strategies, Al-Qaeda constitutes thousands of individuals who have accomplished proper military training (Paul, et al, 2007). Armed Islamic Group of Algeria was founded in July 1992 and became notorious in 1994, after hijacking the "Air France Flight 8969". Since then it has conducted a deadly crusade of killing innocent civilians, bombarding public places, kidnapping and raping in its area of operation. This terrorist group asserts the ideology that "political pluralism is equivalent to sedition". This creed was generated in 1992, after a controversial decision of Algeria's Military Government which blocked the political ways of a mainstream Islamic party, Islamic Salvation Front (Paul Wilkinson, 2007). Taliban derived from the word "students", Taliban is well known for beastly governing the Afghanistan from 1996 to 2001 and its deadly guerrilla war against the NATO including the governments of Pakistan and Afghanistan. This terrorist group was founded by Pashtun tribes with the significant support from some Islamic countries such as Arabs, Chechens, Uzbeks, Punjabis and Tajiks (Richard Jackson, Jeroen Gunning, Marie Breen Smyth, 2009). Aden-Abyan Islamic Army associated to the Islamic Jihad Movement, this Islamic militant group works with the motive to contend against the secularism in Arab countries, significantly in Yemen. This organization was spotlighted in December 1998, after kidnapping 16 foreign tourists in Abyan in which four of the hostages were killed in the rescue operation conducted by the Yemeni security force. Jamaat Ansar Al-Sunna was established in September 2003, this Iraqi guerrilla force opposes the government led by Nouri Al-Maliki as well as the forces of United States in Iraq. This terrorist group is grounded in central and northern Iraq and is said to be linked with several Islamic 
organizations operating in Iraq. However, intelligence agencies of the Iraqi interim government and United States linked this group to Al-Qaeda but later it was revealed that there is a wild conflict between these two terrorist groups. Seeing to its importance the present study was carried out to critical review of causes of militancy and its impact on educational institutions in the world.

\section{METHODS AND MATERIALS}

The universe of the study was the whole world and total 40 studies were downloaded from the net and reviewed again and again and analyzed the situation and conclusion was drawn about militancy causes and its impacts on the education in the whole world

\section{HISTORICAL REVIEW ON CAUSES OF MILITANCY AND ITS IMPACTS ON EDUCATION}

From last thirty years Pakistan has affected a lot due to militancy. It was just the result of taking part of the ethnic, sectarian and clashes for the world power in neighbor's country (Shabir, \& Naeem, 2015). Thus their penalties were not only on the socio-cultural and psychological life of the people but rather it has left worst impacts on the religion and economic structure of the country (Salaman, 2012).In Malakand Division the Militancy was first initiated by Tehreek-e-Nifaze-Shariat-e-Mohammadi (TNSM) led by Maulana Sufi Mohammad, a cleric from Dir Upper, who started his pressure group in 1989 for the increase of Islamic shareia in Malakand Division. This peaceful movement was largely supported by the local people, but the movement gradually changed into a militant organization especially after $9 / 11$. With the passage of time, this Movement became of the larger TehreekeTaaliban Pakistan and created part of the militancy of Malakand Division under auspices of Maulana Fazllullah. The militancy at first started in District Swat and soon spread to all nearby Districts such as Shangla, Dir (upper), Dir (Lower), Malakand and Buner (Aziz, 2010). The roots of the deteriorating state of education in Pakhtunkhwa can be traced back to 1980's when Zia regime laid the foundations of militancy in Pakistan by supporting the US war against Soviet expansion. The fear of terrorism in the province stopped all entertaining activities in educational institutes. Female students felt under pressure for using covers to avoid negative responses from Taliban. Co-education institutes received constant threats of militant attacks. The increasing security measures by educational institutions generated fears among students of the province. Furthermore, the attacks on electricity grid stations in 2009 led to increasing pressures among the students as preparations for exams were troubled to a great extent through expanded power breakdowns. The current rise of militancy has spread a wave of panic among the students. All these mishaps occurred because the Pakistani Taliban's hatred the western education and continuously attack on educational institutes, containing Muhmand, Swat, Malakand, Dir and other agencies; the area near to Afghan border are the strong hold of militancy and affected other part of the country (Rome, 2010).

FATA had always been on low priority agenda of each government in Pakistan before the September 11 terrorist attack on the US. The people of this semi-autonomous region faced enormous difficulties in their daily lives as there were negligible fund allocations for the socio-economic uplift of the region. This was particularly true about the plans and policies with regard to the education sector. According to the figures available, the annual expenditure on education in FATA had been Rs1.5 billion until 2001. During 2004 and 2005, the education budget was nearly doubled, to Rs2.7 billion. However, this increase was practically meaningless: it is estimated that for the provision of universal primary education alone - which is an important aspect of the Millennium Development Goals (MDGs)-another Rs. 1.08 billion are required. This is a grim situation, particularly for the low income groups and the marginalized communities, and especially once the region's literacy rate is $\mathbf{1 7 . 4 2}$ per cent as compared to the 59.6 per cent at federal and provincial levels altogether. According to the official figures of Ministry of Education report on 'Status of Education in Pakistan 2004-2005', there were total of 674,567 educational institutions in FATA. They included primary schools, middle and high schools, higher secondary schools, colleges and seminaries, community schools etc. Following table illustrates the total number of educational institutions in newly emerged districts (formerly Federally Administered Area) FATA in the wake of beginning of military operations:

Table 1 Number of Educational Institutions in Newly Emerged District

\begin{tabular}{|l|c|c|c|}
\hline Institutions & Boys & Girls & Total \\
\hline Private & 90,397 & 5839 & 96237 \\
\hline Public & 399,044 & 179,286 & 578,330 \\
\hline Total & 489,441 & 185,125 & 674,567 \\
\hline
\end{tabular}

Source: FATA Research Centre. (2009)

Number of Students Enrolled in 2004-05:

The enrolment in all the above institutions stood at 613,364 (including the public and private institutions). The details are shown in the table below: 
Table 2 Number of Students Enrolled in Educational Institutions in Newly District Mohanmand

\begin{tabular}{|l|c|c|c|}
\hline Institutions & Boys & Girls & Total \\
\hline Private & 90,397 & 5839 & 96236 \\
\hline Public & 366,410 & 150,717 & 517,127 \\
\hline Total & 456,807 & 156,556 & 613,364 \\
\hline
\end{tabular}

Source: FATA Research Centre. (2009).

Education mean transfer of knowledge and it is the basic requirement of life. Education play very important role in human life. In general education is use full for two reasons. First, human being is not complete without getting education, because knowledge comes from education and education makes the man perfect. Through education development occur and to think accurately to take decision easily. Second, improbable an uneducated person, as comparable an educated person receive information from the world very quickly. As a common dialogue "education is light" and "education is life" this means that education guide the way when man gets hanged. Education is a mixture of thoughts, truths, tradition, trust which established theories and boldness of life. Aristotle to John dewy the education thinker generally study education is not a passive phenomenon but it is an innovator energetic method. (Verk and Jan, 2004).

According to Islamic acquiring of education is the duty of every man and woman. In present era, without education it is very difficult to achieve development and its basic objectives and goals, education is a social instrument, and it is obvious that an illiterate person cannot contribute in the development of a nation, and a person can make his future and can lead fate through knowledge. Education occupies a fundamental place of a country development. There for the country need to spend a huge amount of fund in education i.e. is research and technology. Education plays a vital role in the development of a country. Because education can bring progress, and prosperity in nations. In underdeveloped country the literacy ratio is very high therefore the essential sources of progress is education. To attain modern scientific and technological methods, education is very essential to overcome dissimilar procedures of development. It is education which capable human beings to reach the power of nature and to reach on the planets and unseen sides of space. Education enable people to realize for survive and to protect environment, and to make sure to understand the principle and numerous actions to make powerful belief (Danish, 2011).

Pakistan deployed its troops in the tribal belt after the US invasion of Afghanistan so that Taliban could not make sanctuaries in that area. Wana was the first place where the military operation was launched by the Pakistan Army against militants, and the strategy was followed in South Waziristan Agency in 2004. Afterwards, a series of different operations were carried out against militants in all the seven agencies of FATA, which spread from Bajaur in North to South Waziristan Agency (SWA) in the south. The conflict gained momentum in 2008 when militants spread their activities based in North Waziristan to other agencies of the FATA. However, the people of FATA are the ones who bear the brunt of the conflict in the region. These people are in the direct firing range of ruthless and cold blooded extremists and militants. The militants have brutally slaughtered hundreds of people besides killing thousands of them. Even women and children are not spared. Schools are blown up and tribal elders are indiscriminately targeted. Also, militants have forced people to leave their homes. Pakistan's efforts to stabilize the situation cannot be undermined. The State initially tried to limit the activities of the militants, through a process of talks and negotiations. This however could not succeed and therefore prompted the government to use force. The Government of Pakistan initially attempted to contain the militants through dialogue and negotiations. After these attempts failed, a military operation was launched in early 2009 with the consensus of the political, administrative and military leadership. This operation caused an internal migration in colossal proportions from the embattled areas; an estimated two million people became internally displaced as a result of crisis. While the operation is seen as well intentioned, it has imposed an immense cost on the local economy. Large number of people have been forced to leave their homes and livelihoods and considerable damage has been caused to physical and social infrastructure, particularly educational institutions. The armed forces and police are valiantly tackling the menace and sacrificing their lives but the most crucial aspect of the overall struggle against the militancy is the destruction of education system in FATA. The Taliban in the region were vocal critics of the educational institutions, particularly against women education on so called religious pretexts. However, another reason for their policy of destroying educational institutions stems from the fact that in many areas, these institutions are being used by security forces as their camps, thus making them prime target of the militants. Educational institutions and the people directly or indirectly associated with them were the most to suffer.

Nonetheless, there are striking facts and figures available on the number of destroyed educational institutions for boys and girls (primary schools, middle schools, high schools and colleges).

The following data shows that out of 458 destroyed educational institutions (primary, middle, high and higher secondary schools and colleges) 317 were for boys and 141 were for girls, educational institutions were destroyed by the militants in the tribal region including the Frontier Regions (FR). 
Table 3 Number of Schools Destroyed in Federal Administer Tribal Area Pakistan by Militants

\begin{tabular}{|l|c|c|c|}
\hline Agency/Region & Boys & Girls & Total \\
\hline Bajaur & 68 & 27 & 95 \\
\hline Mohmand & 66 & 22 & 58 \\
\hline Khyber & 31 & 27 & 61 \\
\hline Kurram & 45 & 16 & 34 \\
\hline Orakzai & 23 & 11 & 32 \\
\hline North Waziristan & 23 & 9 & 35 \\
\hline South Waziristan & 29 & 6 & 15 \\
\hline FR Peshawar & 11 & 4 & 32 \\
\hline FR Kohat & 17 & 15 & 4 \\
\hline FR Lakki & 2 & 2 & 458 \\
\hline Total & 317 & 141 & 5 \\
\hline
\end{tabular}

Source: FATA Research Centre (2009)

Note: The schools destroyed include primary, middle, high and secondary schools and a college.

\section{Number of School Destroyed in Muhmand District}

Muhmand District was the chief target of the Tehreek-e-Taliban Pakistan (TTP) militants being led by Moulana Faqeer Muhammad who tried to target schools, both male and female, as a part of their strategy to inflict damage to the government infrastructure for the attainment of political objectives. Besides, they acted this way on the pretext that these schools taught secular education and thus could not be tolerated in an Islamic society. Another reason which was used to justify their act was that most of these schools were used by the security forces as their station camps. The educational institutions affected by blasts in District Mohmand include 7 high schools for boys, 12 middle schools for boys, 46 primary schools for boys, 1 college for boys, 1 high school for girls, 3 middle schools for girls, 17 primary schools for girls, and 1 girls' hostel. Additionally, 86 educational institutions in District Mohmand were completely destroyed which is the highest figure in the list of fully damaged institutions in the region where 46 primary schools for boys were damaged, 15 middle schools were damaged out of which 12 were schools for boys and 3 schools for girls. District Mohmand is also on top of the completely damaged primary schools' list, where 63 were completely destroyed.

Table 5 Total Boys and Girls Schools Destroyed in Mohmand District By Militants

\begin{tabular}{|l|c|c|c|c|}
\hline Gender & High & Middle & Primary & Total \\
\hline Boys & 7 & 12 & 46 & 65 \\
\hline Girls & 1 & 3 & 17 & 21 \\
\hline Total & 8 & 15 & 63 & 86 \\
\hline
\end{tabular}

Source: FATA Research Centre. (2009)

Various researchers defined the phenomenon of 'drop out' differently. According to Jamil et.al, (2010) drop out is "a term used for the children, who for any reason other than death, discontinue schooling and leave their education uncompleted". This is quite broad definition and includes all those students discontinuing their studies without completing their studies for any reason other than the death of the student. This definition includes students at all levels of studies. This also covers those students who are expelled by the education institution due to their week performance or failure in studies. Some of the students discontinue studies due to their illness, may also be included in the above definition of drop out. According to Malik (2002) drop out can be defined as, a student who left school before completing a course of study. This definition does not cover any complexity of the phenomenon and has not clear in substance. This is much generalized definition covering all students quitting their schools prior completing their courses. Umoh (1986) define dropout as, "student who left school before the completion of the program for which they are enrolled, for unseen reasons". This is a flexible definition covering all those students leaving their planned study program for any reason before completion. Hence, this definition of drop out a quite comprehensive definition and focused. The UNICEF and Government of Pakistan (2000) did joint study and they define dropout as withdrawal of children from school at any stage before completion of primary education". they further explain that drop out is a "terminology used for the student who left his/her education incomplete, before the completion of the specific program/level of education for which he/she was enrolled in the school, for any reason, and he/she is no more enrolled in the same level or in any equivalent qualification". Joubish \& Khurram (2011) putted forward that illiteracy, poverty, low level of motivation, lack of understanding, child labor, corporal punishment, teacher behavior and the school environment are such factors that contributing to the dropout at primary level. This study covered factors affecting the drop out of boys and ignored girls drop out factors. This means that the factors affecting the drop out of girls' studies and causing drop out may vary from the factors affecting boys drop out at primary level.

Farooq (2010) studied the drop out factors. He listed a number of factors causing the drop out of student. 
Some of these factors, Farooq (2010) mentioned, included repeated failure of students, poverty as students cannot afford to go to schools, lack of interest in studies as students cannot seek admission in their favorable subjects, the low quality of teachers and teacher behavior with students, and sever physical and mental punishment in schools. However, this study was about the drop out of boys and girls were not included in this study. Studies indicated that poverty is one of the main factors for the drop out of students at primary level in rural areas (Jamil et.al, 2010). Jamil et al., (2010) described other factors for drop out of students including distance of schools, bulky families, overcrowded classrooms, corporal punishment and grade retention. According to Malik, 2002. On one hand, boys are preferred as a source of income and schools going boys are considered liability as providing education to children bring financial burden to parents. On the other hand, in traditional societies, girls are preferred to remain at homes as there school going girls are perceived as threat to honor for their parents. Moreover, girls education may bring more expenses to their parents as parents have to arrange pick and drop facility also for their daughters. Sterns and Glennie (2006) studied public schools in North Carolina and argued that academic failure, disciplinary problems, employment opportunities, populated families, marriages, pregnancy reasons and caring children are factors which contributes to high school drop out of girls and boys. This shows that various societies have different social issues resulting for the drop out of children from the schools. As in the study of Sterns and Glennie (2006), pregnancy, marriages and child caring responsibilities causing drop out of females from schools. Moreover, students' ethnical background, minimum opportunities after education, climate of schools and parents perception towards education are also influencing the enrollment and drop out of children from schools.

Debbie and Jennifer (2004) conducted a study in the University of Taxas at Austin on High School dropouts. They identified factors for the drop out including income of the household, social and emotional factors, race and ethnicity, socioeconomic status, stress for achieving better grades and institutional factors. According to a study of UNESCO and Center for Development Research, Bangladesh(CDRB) (2002), the girls' students are dropped out from school for two main reasons namely severe poverty and the early marriages. In this study poverty is one of the most crucial factor of dropout from school in Bangladesh. Similarly, the early marriages of students are also the major reason for the drop out of students. The phenomenon of the early marriage is further linked with the cultural factors. These factors may also add to the drop out students from the schools in Pakistan as the context of Pakistan and Bangladesh indicate similarities. The perception of parents about education may also important for the enrollment and drop out students from the schools. It is argued that education parents are more inclined to send their children to schools than those parents who are illiterate (Holmes, 2003). The author is of the view that if parents are illiterate then their children are more prone to be dropped out from school. However, it may possible that in some cases illiterate parents may send their children to schools because they may not want their children to remain illiterate. Such parents may want their children to get better education and find good jobs.In Pakistan dropout rate of girls is higher than the boys. Most of the Pakistani population is inhabited in the rural areas. Where especially girls are facing lots of problem, somewhere cultural restrictions and somewhere schools are far away. Especially at secondary level they are facing severe problems. And on average they cover a distance of 10 to $15 \mathrm{~km}$. Which is far away and their parent can't afford it and pulled them out of the school (Stephen, 2007). After consistent attacks, large number of children were excluded by their parents from schools. The education institution was closed for one to two years because of militant group. Afghan commission for Human Right report that in 2006-2008 the number of students were decrease i.e. just 10.52 per cent for girls and 8.0 per cent for boys attend the schools. Due to the highly insecurity and students were directly related to highly unsafely condition. More than 40,000 children were being forbidden from schools at the end of 2009 due to attacks on education institution and the destruction of schools buildings in the country (Kakar, 2008).

Due to harsh situation the government agencies conducted military action in contradiction of the militant group, because a large number of people were rushed and left their home land of Muhmand district (Mir, 2009). The main target of militant group are those areas where inequality and social injustice are prevailing. Basically militant are those people whom are denied from the basic right of the society, that type of people make a group and they wants to take revenge from the whole community in the form of militant group. For this type of activities they need to make their own place through which they controlled their operation, the Khyber Pakhtunkhwa and especially Terror in Federally Administered Tribal Areas (FATA) offers a fuel for those militant group due to socio-economic scarcity of these group. These Militant group are highly salaried by terrorist organization, to target innocent people and security forces for their own benefit. The most significant effect of militancy is the loss of human lives. The new militant attacked that cause much considerable casualties and as well as much destructions. It damages every sectors of life vary badly particularly firm and nations such as military installation, public transportation system, major business related facilities and also tourism. We saw it in World Trade Centre, Marriott hotel Islamabad, Mumbai incident, Night club Bali Indonesia etc. in which many human lives were gone (Husain, 2007). According to the writers Paul R. Ehrlich and Jianguo Liu that the weak system of socioeconomic and demographic structures it make easier for the militant to be enlisted. The 
Bush administration didn't give attentions and ignores all of them. These variables can be measures and evaluated easily as compare to cultural and individual factors which is very difficult to be examine. We do not say that these are the only factors in promoting terrorism. But these factors are very important and can easily be evaluated. (Harris, 2004). Population growth also plays an important role in the political instability. Most people ignore the age composition which is the cause of poverty and other determinants. Most of the terrorists belong to the young adult age. In 2001 most wanted terrorist list, $90 \%$ on the list all of them were male and in between from 22 to 34 years of old age. Ages of twenty suicides were between 16 to 28 years. By 2050 almost $23 \%$ of the male in the developing nations will be in the range between 20 years to 34 years and only are less than $17 \%$ of the above range will be from the countries. The Job opportunities will be decrease with such poor economies of the countries. The growth rate of population increasing almost $2.82 \%$ between the ages of $20-34$ years but it is only $0.16 \%$ to above range of the developed countries during 2000-2050. Due to this growth of population the Job opportunities will be minimum. Most of the unemployed affected young men as they see the west who consider them as enemies represent themselves in the shape of terrorism. Many people believe that the rate of population when increasing is also a hurdle for the development. It also creates the gap between the rich and poor. The increase in population in different nations of people (e.g. ethnic groups, religious) also make the situation that creates terrorism. E.g. in the Israel the Jewish population is increasing with a high rat which create tension and cause of threatening among other things which make Israel unstable as a welfare system state (Alex, 2004).

A fundamental sector group also become against other sect in the same country in order to gain equal political status in the same society. This is also giving breeding to terrorism. Extremist show great rigidity towards other believers and show himself enemy of other religious. Non-religious is against other religion but when religions extremism is to gain political objectives it assume the shape of terrorism. The prophet of Islam does not produce violence or breed extremism. Religious extremism were also emerged in India because of the existence of certain subgroup minorities which were propagating by the Hindus extremist organization. This kind of religious fanaticism assumes terrorism. It did not lead to a great movement of terrorism but the existence of its possibility cannot be ruled out. It was happened in Mumbai in March 1993 that a terrorist organization was come into existence. After the partition of Indo Pak the fundamentalist Hindus builds such an extremist groups and they were telling to the Hindus that they should protect their religious identity as the Muslims and Christian doing, but there was no need of such claim. Their claim was reflective of religion being manipulated by political and they were achieving political objectives rather to protect their religion (Ahmad, 2004). The reality of political complaints in a particular subgroup of a country or even in the greater population of a country of a subgroup for example the ethnic minority objections discriminated against the majority. Due to these objections among different people of the same sub group, a social movement develops this subgroup trying to gain their equal rights or even a separate state for their self. Terrorism than start by this broader movement of an extremist faction. In a real way terrorism arises in such a condition in modern states like the separatist patriotism among Basques Bretons has motivated terrorism. This nationalism has been converted into terrorism in the colonial era. In most of the states they do not gave their rights to a particular subgroup for example they may be a religious group or a separate nation from the majority. For obtaining their rights they develop a social movement. Due to this ineffective struggle a wave of disappointment has been arises in this particular subgroup against the majority. This social movement changed into terrorism. Another motive is that types of terrorism is lack of providing opportunity in political participation. (Alex, 2004). Rao (1985) conducted the study regarding the importance of children education in urban and rural area of Pakistan. He stated that an educated people are who can educated their children in early age and are better teacher for early schooling and play great role in socioeconomic uplifting their family while educated female kept a high position in her community. Sehira (1996) stated that the attitude of Pukhtoons culture regarding women education found negative view that women are not allowed to go to school to get education, the study also found that majority of sample respondents were illiterate in the study area. The majority of the rural people were illiterate and they belong to lower socio-economic group. They have strict cultural norms and values that's why they do not realize the importance of girl's education.

Mukaram (1999) analyzed that the attitude of people towards female education and concluded that most of the people were illiterate because of rural prejudices against female education. The main reason of economics condition and cultural values of the people do not allow them send the female children to schilling to them other place. Some groups feels that the female education is useless. Khan (2000) investigated a study on issues and problems of women education. He also report that certain people do not give right to women to get education due to poverty. Some people not sending their children because of unawareness the importance of education i.e. strict cultural and social condition of the area. World Bank (2000) reported that education system need to be proper and well organize polices for female education. The study was conducted with the aim to investigate the initiative taken by World Bank for the achievement of betterment in female education: to improve the quality of education. This research exposed the issue and its success for female education is a part of whole dynamic, which overlap and work together in socio-cultural schools and institutional factors. Krueger and Maleckova 
(2002) concluded that education and poverty have informal connection between each other. This research also studied that mainly the poor people are engaged in criminal groups i.e. are joining militant activities and disturbed the whole socio-economic and political systems of a country. This may create a high rate of hatred illegal actions typically self-reliant and economic conditions. Statically this paper study the causes of attractive part in Lebanon by Hezbollah in terrorist activities. The result shows that what reason on why knowledge and profitable conditions are essentially not related to taking part and to support militancy. Evanko (2004)analyzed the connection between different educational variables and militant attacks in Middle Eastern and South Asian regions during the years 1997 till 2007. His study based on panel data, time series data, for the analysis of data he applied statistical test known as regression, to find out the relationship between the variables. The regression model used to check educational variables like literacy rate, ratio between male and female, and its effect on primary and secondary level.

Behraman et al (2004) mentioned that educated woman can play a pivotal role regarding her children's education. He also states that educated mother can easily guide her children to a right path and she can become the best possible tool for achieving a great target in education. Mother is infect a primary source of education for her children but in this regard an educated woman can prove as a best educator for her children. Those children whose mothers are highly educated their children will have high educations and can also be proved as a good citizen and a factor for development of a nation. Skinner (2004) reported that primary education for male and female has a very significant and a much positive effect on children lives. Primary and secondary education has increased from 38 to 68 per cent in 1970 to 1992 in the developing countries such as Arabic states, Southeast Asia and Sub-Saharan Africa. Education improves child health, declines child's mortality and increases child's school achievement. First, educated parents are more likely to have educated children, when parents have a certain level of education; they always tries their best for their children to do likewise or even better condition. Fair and Shepherd (2007) analyzed the terrorist attacks of 9/11. He told that the suicide terrorism have proliferated in the United State. A Lot of these studies have paying attention to main manpower of the terrorists. These findings showed that terrorists tend to be male, better educated, economically deprived backgrounds. The findings of various studies have been mixed with respect to marital status and tendency to be a terrorist. Wiki and Fraser (2009) examined that targeting schools are non-sense work. But there are different ways through which terrorist's gets encouragements and to discourage these elements there are six possible strategic cautions: a).Decreasing civil violations, b) Arranging different programs for vulnerable students. c) Increase commutations with in educational boundaries and also increase resources. d) Make sure human protections, f) Implement code and conduct of peace, g) Increase schools in the area. Mir (2009) concluded the character of Militant in Pakistan is affecting the country seriously socially and politically, he further state that the country is giving human sacrifice and spending huge money by playing this leading role in war on terror. Due to presence of terrorist it is very difficult to count or evaluate human loss in political instability in war affected region. Pakistan has lost developmental speeds, power and also economical loss of 35 billion US\$ since 2001-2002.

Khan (2011) reported that due to militant's attacks Pakistan suffered. The educational sector and economic conditions, they also targeted female educational buildings especially. Because of this insurgency, education has been brought down. Due to this insurgency, in Malakand division thousands of students and employees were affected. Large number of schools were destroyed. The insurgency was highly effected our education system, 150 thousand were dropout, $75 \%$ teacher became jobless and 68\% schools in district Swat were destroyed i.e. completely or partially, $36 \%$ schools were demolished in lower Dir, Buner and Malakand divisions. Naqvi et al (2012) stated that the war on terror make a great disturbance in the area, especially in Khyber Pakhtunkhwa in Federally Administered Tribal Areas (FATA). The Militant group need to control over the area for the need of man power from that area. For this purpose they destroyed a large number of educational institutions in the area. Because if the local people get education they became aware and against of them due to which they loss their hold in area, and could not achieve their goal. Militant group has taken away the basic right of human being i.e. education and also unsecure their life. Wieseltier (2012) investigated that targeting and blasting of schools building left bad impact on girl's education ratio in district Swat. Mala yousafzai, a young educational campaigner, was also targeted by militant in this regard. After destroying female's education in Swat. Taliban claimed that Mala was targeted because of having and spreading liberal thoughts in the society, and they also rejected to opposing education in the area. Javaid (2012) concluded in his study that war made insecure and deprived the area where the militant operation take place. Which affect the social, political and financial structure, of the area. By continues militant attacks in the form of bomb blast and suicide attacks and kidnapping. The local people were facing difficulty to live in this situation there for the government need to take complete action to curb this situation and to clear the area. Otherwise it's very difficult for those who live in that area to get education and economic development and the ultimately its effect the overall country prosperity.

Ahmad (2012) concluded has work on female education and Taliban in two countries, Pakistan and Afghanistan, especially with a case study in Swat district. He further elaborated that Taliban's increasing power is a greatest issue for both the countries, as well as for NATO forces. They are not only the headache of 
government but also threatens general public it has changed overall system of education in both the countries as well. The study concludes that education makes a person wise, it is a helping source for growth and development, which enhances female's social and production problem. The aim of this research to give special concentration on girl's education during Taliban region. And also to find out alternative sources to familiarize with modern age issue if Militants have any alternative for modern education system. Afzal (2012) reported that in 2009 , conducted a survey which shows that supporting militancy and modern education different on gender base. Same is the case that educated women will be less expected to participate in militant activities as compare to educated man. An illiterate women will comparatively be expected more to be the supporter of militancy as compare to illiterate man. Due to the education of female one can be easily have control over militant activities. The effectiveness of female literacy can be determined by passing their time in schools. On the other hand there have been found in survey that more illiterate female are likely having more negative point of views against US and illiterate female can have positive view regarding militant attacks on US, as compare to man. He gives the example of Swat district, which is the possibility might have omitted reality exposing factor. Sheikh (2013) reported that militants demolished 831 schools in 2009-2012 in Federally Administered Tribal Areas. This may revealed that the education system of (FATA) is very miserable condition. May 2009-2012 Federally Administered Tribal Areas (FATA) and Khyber Pakhtunekhwa. The important source of data collection was (PIPA) Program on International Policy Attitude in 2009. The (PIPA) is a national representative and it has a very low voting rate, and it is a large number of questions(less than 10 per cent for most questions). This paper uses 2009 polling data for those who responded level, which has not yet been carefully studied at that level. And the data regarding 2007 are totally against of militant groups. Buser (2013) investigated that Determined the role of Taliban in Afghanistan stop female to go to school for the implementation of Sharia Law. This religious "moral code" impose harsh social duties on citizens. The government of Afghanistan provide funds for different schools, colleges and universities that put forward better educational chances for male and female, in Kabul city. Yet, outside the city the possibility to receive quality instruction decreases significantly, for girls and women. A large number of people living in rural areas a totally against from getting education for their sister and daughter, because they are not willing to a dowry or to fulfill other "female obligations" the literacy rate in Afghanistan male 43.1 percent and female rate is just 12.6 percent which show a big difference between male and female education.

Singh and Shemyakina (2013) stated that Indian Human Development survey on 2005 for having long term impact for education in insurgency affected areas of Punjab during 1981-1993, in which 6 to 18 years old children were getting enrolment. It brought negative effect on education and they faced hardships in getting their children educated in violence affected region. Yunas (2013) studied that the rise of Talibinzation in tribal region then spread to settled areas, which affected every sphere of life including education. Hundreds of thousands students were affected in different districts of the province, out of which female ratio is 50 percent almost. Female's school and institution were mostly hated by militants and both teachers and students were given orders to stay at their homes otherwise will face deadly effects as it is Islamic preaching. According to government officials. A large number of schools have been destroyed by militancy and millions of students suffered their educations. The official said that they have tried to recover this loss by spending 12 billion rupees in education sector. He further said that to come of this unbalanced situation, government has established tent schools and has started evening shifts beside of substituted arrangements. Waqar and Tawakkal (2013) stated that militancy and terrorism in the country have made severely insecure situations and bad effect on female. They have blamed government that it is the failure of law enforcement agencies to have control over these militant group which is seriously dangerous. Females have been blamed as a western agents and also attacked by Taliban. Number of incidents have been listed lie for example in 2008, in Kohistan female were not allowed to participate in election, in December 2012 polio workers have been killed; it also discouraged and deprived women in the country. Adnan et al 2017 conducted study in district Swat. The major objectives of the study were to examine the impact of militancy on primary education in the study area. Purposively union council Charbagh was selected in district Swat on the basis of sever causalities which consists of 25 schools, $80 \%$ govt. and $20 \%$ private schools. Through questionnaire the head masters of the schools were interviewed and data were collected from sampled respondents. Descriptive statistics were used for analyses. According to results $68 \%$ schools were found scratched while $32 \%$ found safe. Sixty eight percent schools were recorded closed for more than 12 months, while $32 \%$ for $9-12$ months. After restoring the peace different temporary schools, such as, shelters, rented schools, community and Madrassa schools were settled for education while some problems were recorded such as distance, harsh weather, congested settings and lack of furniture etc. In some schools the strength were found less than before while in some found more. Majority children and teachers were found absent due to terror from schools because of this in time the syllabus of course was not completed. Seventy seven percent destroyed schools were reconstructed and repaired while $23 \%$ school building were left due to lack of fund. Few recommendations were suggested for future policy implications. Compromise between militant and Government of Pakistan is requested for peace restoration in the study area. Tight security and honest staff for security 
purpose should be deployed in the study area. Sufficient funding is required for reconstruction of damaged schools in the study area. Loan should be provided to whole community on free interest basis. Check and balance should be imposed on surrounding boundaries to stop foreign terrorists' entrance in to the country. Khan and Adnan conducted study in Feb, 2018. The major objective of the study was to critically review the past literature of militancy impact on educational institution in the study area. Total 35 reviews were selected for the study. All past reviews were read 20 times and analyzed the militancy impact on educational institutions in the world. The result indicates that militancy has scratched the educational institutions and declined the number of students and teachers presence and attendance in the Schools, Colleges and Universities due to fear and terror. However terror creates anxiety and mental torture which affect the health in the long particular female students and teachers which badly influence the quality of education while adversely affects the economy and socio economic condition, particularly the developing countries of the world. The result further explains that poverty is the main cause of militancy in the world. So the results concludes that there is a militancy there will be more disturbance and low level development where high poverty, illiteracy and other social conflicts were the fate of that country. On the basis of findings the study recommend:- Compromise between militant and Government forces of the world; Tight security and honest staff selection in the military of the government for controlling the situation in time; All Madrasas supervision by government of the world. Sufficient funding provision for militancy control; infrastructures development by government for easy access to militant. Tourism spots, hilly area and hidden places check and balance in the country; Loan provision to whole community on free interest basis for investment in the area for poverty eradication; Marble industry development for generation of employment in hilly area for occupation provision for poverty suppression in the world and population Identity Card Registration etc

\section{CONCLUSION AND RECOMMENDATIONS}

Militancy is thus defined that any struggle that is made violently for the achievement of cause or interest is said to be militancy. Review of related literature shows that militancy is causing aggression in society in terms of cause and interest. In every society the militants are the production of socio-economical imbalanced systems. It also explores that poverty prevailed in society is mainly causing militancy. Thus militancy is not only affecting economy (in terms of spending money on war of terror) but can also have impacts on the physical shape of the society. Insecurity in educational sectors increases illiteracy (dropout rate). While terrorist attacks are directly creating fear and psychological diseases like anxiety etc. among both the parents and students and even in teachers as well. Especially those students whose institutions are once targeted or still under influence of terrorism are avoiding education and they are suffering directly and facing bad consequences in future. The militancy raised due to poverty and illiteracy in the world which further used by some leader for their gaining for their particular objective. They deceived to these poor illiterate community and unite them against the government which latter on became militant which have weapons which used against the government and destroyed to schools and colleges and make the country environment unfavorable and create terror in the world for pressurized the government. On the basis of problems the study recommended that to generate employment for reduction of poverty and established school and colleges for the improvement of their skill to find job easily anywhere in the world for pushing their economy.

\section{ACKNOWLEDGEMENT}

Dr.Himayatullah, Dr.Shanaz Akhtar and Dr.Malik shafi have helped in synopsis preparation and they are also highly acknowledged in this paper for good suggestions.

\section{AUTHORS CONTRIBUTIONS}

Alamzeb Khan is the student of Ph.D and during synopsis preparation he created the idea for paper preparation from his synopsis while Dr.Naushad Khan as a advisor helped in writing and he supervised the paper to the end of publication.

\section{REFFERENCES}

[1] Afzal, M. 2012. Are the Better Educated Less Likely to Support Militancy and Terrorism? Women are. Evidence From a Public Opinion Survey in Pakistan, School of Public Policy, University of Maryland.Pp.69.

[2]. Adnan M., N.Khan and Farhatullah, 2017." Militancy Impact on Primary Education in Union Council Charbagh District Swat-Pakistan”. Journal of Culture, Society and Development www.iiste.org ISSN 24228400 An International Peer-reviewed Journal Vol.36.Pages 7-11

[3]. Ahmad, S. 2012. The Taliban and Girl's Education in Pakistan and Afghanistan- (A Case. Study of the Situation in the Swat District).

[4]. Aziz K. 2010. Swat: The Main Causes of the Breakdown of Governance and Rise of Militancy" Peshawar, 
p. 53.29

[5]. Ahmad, 2004. Islam, Democracy and Citizenship Education: An Examination of the Social Studies Curriculum in Pakistan. Current Issues in Comparative Education 7(1): 39-49.

[6]. Alex, P. Schmid. 2004. "Frameworks for Conceptualising Terrorism." Terrorism and Political Violence: 197-221.Vol 16.2

[7]. Behramn J. R, Adam J. G. et al. 12 February (2004) “Women's schooling, home teaching and economic growth" The journal of political economy 107:4 Jstor Mann library of Cornell University.

[8]. Bloomberg, 2004. The Macroeconomic Consequences of Terrorism. Retrievedhttp://www. Econstor.eu/bitstream/ 10419/76482/1/cesifo_wp1151.pdf, (accessed 10 October 2015).

[9]. Debbie Blue and Jennifer E. Cook, 2004. High School Dropouts: Can We Reverse theStagnation in School Graduation? (PhD Thesis, University of Texas, Dept. of Education).

[10]. Evanko, K. 2004. "Enhancing Education Policy in the Middle East and SouthAsia: An Investment in Terrorism Prevention or An Inefficient Use of Counter Terrorism Resources a Thesis to the Faculty of the Graduate school of Arts". http://unesdoc.unesco.org/images/0018/001868/186809e.pdf $>$ [accessed:26.04.2012].

[11].Farooq, R .A. 2010. Education System of Pakistan: Issues and Problems. Asia Society for promotion of Innovation and Reforms in Education. Islamabad: Pakistan (pp.10-20).

[12].Fair, C.C and B. Shepherd. 2007. Who Supports Terrorism? Evidence from Fourteen Muslim Countries.

[13].Fedral Administer Tribal Area Research Center 2009.

[14].Hussain.Z 2007, Frontline Pakistan: The Struggle with Militant Islam, New York: Columbia University Press, 2007.

[15].Holmes,J, 2003. Measuring the Determinants of School Completion in Pakistan: Analysis of Censoring and Selection Bias," Economics of Education Review 24: 7-19.

[16]. Jackson R, Gunning J, Smyth M.B. 2009. Critical Terrorism Studies: A New Research Agenda. Taylor \& Francis. p 162.

[17]. Jamil Asif, Atta Amer Malik, Baloch Jalil-ur-Rehman, Danish Ehsanullah, Younis Muhammadand Siddiq Saiqa, (2010) "Parents' and Teachers'Comprehension on Determinants of Early School Dropouts," World Applied Science Journal 11.12: 1488-1493

[18].Joubish F. Muhammad and Khurram A. Muhammad, (2011) "Determining the Factors Influencing Dropout in Government Primary Schools of Karachi," Middle-East Journal of Scientific Research 7.3: 417-420.

[19].Khan, F.A. 2000. Problems and Hurdles of Female Education of District Swat. Unpublished Thesis, Department of Social Work, University of Peshawar.Pp45

[20].Khan N. and M.Adnan 2018. Critical Review of Past Literature of Militancy Impact on Educational Institutions in the World. Historical Research Letter www.iiste.org ISSN 2224-3178 (Paper) ISSN 22250964 (Online) Vol. 44.Pages 11-34

[21].Krueger, A \& J.Maleckova. 2002. Education, Poverty, Political Violence And Terrorism: is There a Causal Connection? (Nber woeking paper no. 9074).”Journal of Economic Perspectives, 2002, 17(4): 119-14

[22]. Muhammad, M. 2002. Decentralization of Education System in Sind A Critical Review. (pp.10-18). Islamabad: Ministry of Education, Pakistan.

[23].Mukaram L.1999. " The Attitude of People Towards Female Education of District Peshawar'. Unpolished Thesis. Department of Social Work, University of Peshawar.

[24]. Malik M. Zahid, 2002 “Causes of Dropout in Primary School,” Pakistan Journal of Applied Sciences 2.6: 646-648

[25] Wilkinson P, 2007. Homeland Security in the UK: Future Preparedness for Terrorist Attack Since 9/11. Taylor \& Francis, p. 56

[26] Fazal Ur. 2003. Pakistan and the War on Terrorism. Strategic Studies, Vol. XXIII

[27].Rizvi, Hasan Askari. 2005. Theoretical Formulations on Terrorism.' In Global Terrorism, Genesis, Implications Remedial and Counter. Terrorism Edited by Institute of regional studies, Islamabad: Institute Of Regional Studies.

[28] Rome, S. 2010. Crisis and Reconciliation in Swat; Pakistan: A journal ofPakistan Studies 3(1): 53-79.

[29].Research Centre for Public Policy. 2009. A Socio-economic Baseline and Displacement Impact, Institute of Management Sciences, Peshawar, p.13

[30]. Salman B. 2012. Socio-economic Conditions of Post Conflict Swat: A Critical Appraisal, Tigah, a Journal of Peace and Development, Volume II. Islamabad: FATA Research Center.

[31].Shabir, H. Naeem, A. and Ihtisham, P. 2015. Impact of terrorism on economic development in Pakistan; Pakistan business jeview $2015 . \quad$ Availableon: https://www.researchgate.net/publication/271079363_Impact_of_Terrorism_Economic_Development_in_P akistan

[32]. Sehira N. 1996 “' The Attitude of Pukhtoon Toward Female Education, Unpublished Thesis. Department of 
Social Work, University of Peshawar.

[33]. Skinner, V. 2004. Education Article 20042.7 April 2004, www.bartledy.com.

[34]. Stephen.2007. McCutcheon, Education in Pakistan, Available athttp://www.r4e.org/education.

[35].Stearns, E., \& Glennie, E. J, (2006) "When and Why Dropouts Leave High School," Youth \&Society 38.29: 29-57.

[36]. Holmes,J, (2003) "Measuring the Determinants of School Completion in Pakistan: Analysis of Censoring and Selection Bias," Economics of Education Review 24: 7-19.

[37]. Harris, Ian. 2004. "Peace Education Theory." Journal of Peace Education 1(1): 5-20.

[38]. Umoh, S.H, (1986) "Comparative Study of Perception of School Dropout by Principal and in Selected School in Kwara State," The Nig. J. Guidance Counseling. 2: 15-25.

[39].UNESCO-CDRB, (2002) "A Study of Girls Dropouts and Non-Completion of Program in the Primary and Secondary," Education in Bangladesh.

[40]. World Bank. USA. 2000. Girls Education the Role of Educational Policies in Mauritania and Guinea. No.171: 3.Indu.com/features/kids/importance-of-education/article4619651-ece.[Accessed: 12.04.2013] 